\title{
TOMÁS GUEVARA: TRAJETÓRIA E (DES)ENCONTROS COM MANUEL MAÑKELEF*
}

\author{
TOMÁS GUEVARA: TRAYECTORIA Y (DES)ENCUENTROS \\ CON MANUEL MANNKELEF
}

\author{
Mariana Moreno Castilho**
}

\begin{abstract}
Tomás Guevara, diretor do Liceu de Temuco (1900-1913), desenvolveu muitos estudos etnográficos sobre o povo mapuche no período em que viveu nesta região, a qual recém tinha sido incorporada à soberania do Estado chileno no processo de (des)ocupação do território mapuche. Guevara desenvolveu muitas obras com ajuda de Manuel Mañkelef, professor mapuche, que trabalhou no Liceu de Temuco. Além de escrever livros sobre o povo mapuche, Guevara também participou dos congressos de Educação, entre os anos de 1902 e 1912, expondo a metodologia de educação indígena. Este artigo abordará a concepção de "predisposição característica do bárbaro", presente na metodologia educacional de Tomás Guevava para os povos indígenas, assim como desvelará a sua relação com Manuel Mañkelef.
\end{abstract}

Palavras-chave: Tomás Guevara, Manuel Mañkelef, chilenidad, educação.

Tomás Guevara, rector del Liceo de Temuco (1900-1913), desarrolló muchos estudios etnográficos acerca del pueblo mapuche en el período en que vivió en esa región, la que recién había sido incorporada a la soberanía del Estado chileno en el proceso de (des) ocupación del territorio mapuche. Guevara desarrolló muchas de esas obras con la ayuda de Manuel Mañkelef, profesor mapuche, que trabajó en el Liceo de Temuco. Además de escribir esos libros acerca del pueblo mapuche, Guevara también participó de los congresos de enseñanza, entre 1902 y 1912, exponiendo acerca de la metodología de la enseñanza indígena. En ese artículo se abordará la concepción de la "predisposición característica del bárbaro", presente en la metodología de enseñanza de Tomás Guevara para los pueblos indígenas, así como develará su relación establecida con Manuel Mañkelef.

Palabras claves: Tomás Guevara, Manuel Mañkelef, chilenidad, enseñanza.

\section{Introdução}

Este artigo abordará a concepção elaborada por Tomás Guevara de "predisposição característica do bárbaro", circunscrita em sua metodologia educacional para os povos indígenas, assim como desvelará a relação estabelecida com Manuel Mañkelef, por meio de Las últimas familias i costumbres araucanas (1913) e da epistolografia trocada com Rodolfo Lenz (1863-1938).

Rodolfo Lenz, assim como Tomás Guevara, desenvolveu muitos estudos etnográficos sobre o povo mapuche, porém com uma abordagem linguística. Nascido em Halles, Alemanha, formou-se em Filosofia pela Universidade de Bonn (1886) e, em 1889, foi contratado pelo governo chileno para ensinar no Instituto Pedagógico da Universidad de Chile. No Chile, lecionou no Instituto Nacional, assim como foi um dos fundadores da Sociedad de Folklore Chileno (18/07/1909) e um estudioso do mapundugun. A epistolografia de Manuel Mañkelef e Lenz revela a aproximação desses dois intelectuais diante do distanciamento entre Mañkelef e Guevara, ambos colaboradores da Sociedad de Folklore Chileno (Memoria Chilena 2014).

Cabe realçar que Manuel Mañkelef e Tomás Guevara estabeleceram relações próximas: lecionaram no mesmo Liceo de los Hombres de Temuco; participaram da Sociedad Caupolicán e da Sociedad de Folklore Chileno; Mañkelef colaborou também com Guevara na realização de livros, como Las últimas familias $i$ costumbres araucanas (1913). Nessa obra etnográfica desvela-se a relação de poder e de tensão interétnica, que sempre justapôs o convívio entre os dois.

\section{Educação de filhos de longkos e Domingo Faustino Sarmiento (1811-1888)}

Manuel Mañkelef, filho do longko Trekaman Mañkelef e da cativa chilena Trinidad González, teve acesso à educação tradicional, assim como tantos

\footnotetext{
* Resultado do projeto de pós-doutorado no Departamento de Historia da FFLCH/USP, bolsista da Fapesp.

** Universidade de São Paulo, bolsista da Fapesp, São Paulo, Brasil. Correo electrónico: mariana.castilho@gmail.com
} 
outros filhos de longkos. Essa tática foi instaurada no transcorrer do século XIX por oficiais, como Cornelio Saavedra e Gregorio Urrutiá, visando estreitar os vínculos com os longkos, por meio do apadrinhamento e da educação de um dos seus filhos (Guevara e Mañkelef 2002 [1913]).

Conforme José Ancan Jara esclarece, a estratégia de educar esses jovens mapuche, civilizando-os dentro dos moldes chilenos, com o intuito de reproduzirem essa tática civilizatória em outros, "não era fruto do azar" (Ancan 2014: 4). Ao proporcionar aos mapuche a educação tradicional, formando-os como preceptores normalistas, o governo visava não só a preparar funcionários para o território recém anexado ao Chile, como também utilizá-los como vetor para para difundir a chilenização entre os demais mapuche.

Muitos desses filhos de longkos tornaram-se intérpretes e tradutores, como foi o caso de Lorenzo Coliman, um dos colaboradores de Tomás Guevara, e Manuel Antonio Neculman, um dos professores de Manuel Mañkelef, na primeira escola da Araucanía. Como constata Tomás Guevara em "Enseñanza indíjena":

\begin{abstract}
A história de um dará a conhecer a sorte que acontecia a todos. Lorenzo Coliman, nosso colaborador em muitos pontos de sociologia araucana, é filho de um cacique de Puren. Depois de adquirir na missão de Collipulli os conhecimentos primários, ingressou em 1876, por intermédio do coronel Saavedra, na Escuela de Preceptores de Santiago (Guevara 1904; I: 173).
\end{abstract}

Assim como Lorenzo Coliman, Manuel Antonio Neculman também estudou na Escuela Normal de Preceptores de Santiago. Nascido em Metrenco, em 1854, filho do cacique Huenchumilla Calfumán, Neculman foi entregue para o militar chileno Orozimbo em um acordo de paz. Em 1881, foi contratado estrategicamente como intérprete e conselheiro do general Gregorio Urrutia. Após a ocupação de Villarrica, em 1883, fundou e dirigiu a primeira escola da Araucanía, em Temuco, sendo um dos primeiros professores mapuche de educação tradicional chilena de que se tem registro. Assim como Tomás Guevara e Manuel Mañkelef, Neculman participou da Sociedad Caupolicán, ocupando o cargo de presidente (Pinto 2003: 205).

Cabe ressaltar que, uma vez ocorrida a ocupação militar de Villarrica, em 1883, no processo de (des) ocupação da Araucanía, o Estado chileno promoveu de 1884 a 1927 a radicação dos indígenas e a delimitação das reduções. Essa prática consistia em conceder títulos de mercedes aos longkos (caciques), restringindo o povo mapuche a viver em espaços reduzidos chamados reduções (Bengoa 2000: 360).

Destarte, o apadrinhamento de um dos filhos de longkos, como foi o caso de Lorenzo Coliman e Manuel Antonio Neculman, foi o desdobramento dessa estratégia do governo chileno para consolidar a dominação territorial (Boccara e Seguel 1999: 742).

Muitos desses filhos de longkos, como Lorenzo Coliman e Manuel Antonio Neculman, estudaram e moldaram seu imaginário social na Escuela Normal de Preceptores, a primeira na América Latina, fundada por Domingo Faustino Sarmiento (1811-1888), em 16 de janeiro de 1842 (Ancan 2014: 2).

Domingo Faustino Sarmiento foi um intelectual argentino que se exilou no Chile, para fugir da perseguição de Juan Manuel de Rosas, sucessor de Facundo Quiroga. A obra escrita por Sarmiento em seu exílio, Facundo ou civilização e barbárie, de grande repercussão na América Latina, foi publicada preliminarmente no jornal El Progreso, vinculado ao Partido Conservador chileno. Na trama discursiva desse livro, Sarmiento propalou a difusão dos conceitos de civilização e barbárie, tornando-se uma referência no meio intelectual desse contexto de formação das identidades nacionais latino-americanas (Prado e Pellegrino 2014: 92).

Conforme escrevem Maria Ligia Prado e Gabriela Pellegrino: "O texto de Sarmiento ganhou enorme repercussão e sua interpretação da divisão da sociedade e da cultura em civilizados e bárbaros marcou a visão das elites letradas da América Latina”. No olhar dessa elite intelectual, civilização remetia ao branco europeu, enquanto o bárbaro correspondia aos povos indígenas, afrodescendentes e camponeses (Prado e Pellegrino 2014: 92).

Essa dicotomia de civilização versus barbárie, proposta por Domingo Faustino Sarmiento, evidentemente repercutiu também na Escuela Normal de Preceptores, que, por sua vez, ilustrava a maneira como o Estado nacional chileno desejava formar os cidadãos. Iván Núñez Prieto pondera que, diante da influência positivista, a "moralização" na Escuela Normal de Preceptores ocupou lugar de destaque. Prieto afirma: "Os 'civilizadores' da massa popular tinham que ser civilizados. Para isso, poucos anos depois de fundada, a primeira normal - e as seguintes - se converteu em internato, com forte $\mathrm{e}$ 
desmedido sentido disciplinante" (Núñez 2010: 35). Dentro dessa ordem discursiva, a Escuela Normal de Preceptores desejava superar o concebido como bárbaro, com o instaurar da suposta civilização.

Apesar de Manuel Mañkelef não ter feito parte do pacto militar, característico do final do século XIX, teve a sua formação superior e normalista, integrando a primeira geração mapuche a inserir-se no sistema escolar tradicional do começo do século XX. Por ser normalista e por ter estudado na escola onde Manuel Antonio Neculman foi diretor, em Temuco, Mañkelef acabou recebendo vestígios do pensamento de Domingo Faustino Sarmiento (Ancan 2014: 6).

\section{"Problema indígena" e a concebida solução educacional}

Manuel Mañkelef, assim como Lorenzo Coliman, por dominarem o mapundugun e a cultura mapuche, exerceram papel fundamental no desenvolvimento das pesquisas etnográficas de Tomás Guevara. Em Folklore araucano (1911), Guevara reconheceu a importância da colaboração de Lorenzo Coliman e Manuel Mañkelef nos seus trabalhos:

Tem servido com toda a eficiência em tão difícil trabalho Don Manuel Manquilef, jovem estudioso, normalista e atualmente professor do Liceu de Temuco, que domina a língua de seus mais velhos e de seus dominadores. Secundariamente aproveitou os conhecimentos e a boa vontade de Lorenzo Coliman, e de Felipe Reis, de estirpe araucana, ainda que seu sobrenome seja espanhol (Guevara 1911: 3-4).

Entre as obras etnográficas de Guevara encontram-se: História de la civilización de la Araucanía (1898), Costumbres judiciales $i$ enseñanza de los araucanos (1904), Psicolojía del pueblo araucano (1908), Las últimas familias i costumbres araucanas (1913) e Araucanian Silver Plate (1925).

O interesse de Tomás Guevara pelo povo mapuche reflete em parte a angústia intelectual de construir a idealizada chilenidad. Bernardo Subercauseaux realça que, "no final do século XIX e nas primeiras décadas do XX, no Chile, como em quase todos os países da América Latina, houve um ativo processo de construção da identidade nacional" (Subercaseaux 2011; I: 217). Ao entender a chilenidad como uma unidade homogênea, houve uma mobilização dos intelectuais para excluir as diferenças culturais.

Devido à influência das teorias raciais provindas da Europa e dos Estados Unidos, como o evolucionismo e o positivismo, excluir a diferença, para os intelectuais chilenos, significava realizar um genocídio ou um etnocídio, justificado pelo cientificismo do que seria uma raça "superior". Dessa forma, como aponta Richard Graham, inserido nesse contexto, surgiu o "problema indígena" (Graham 2006: 803).

Tomás Guevara, assim como muitos desses intelectuais, sofreu influência das teorias positivo-evolucionistas. Convém recordar que Guevara, além de ter tido formação normalista, e de ter feito parte do meio intelectual em que essas teorias circulavam, sofreu influência direta também do imaginário social presente no contexto das batalhas militares, como a Guerra do Pacífico (1879-1883), e das comemorações do Centenário.

O pensamento racial e as teorias positivo-evolucionistas ocuparam lugar de destaque no imaginário social do final do século XIX e começo do XX. Mañkelef, em uma das cartas escritas para Rodolfo Lenz, desvela esse imaginário ao convidá-lo para hospedar-se em sua casa de Temuco, anunciando:

\begin{abstract}
Venha em fevereiro e já estarei (porque você terá que vir como amante das ciências), preparem-se para um quarto indígena. Minha casa está a três quadras da Praça das Armas e em fevereiro o esperarei; hoje em dia tenho mais comodidades do que antes, por ser agora casado e ter cordeiros para comer nessa data.

Prometa-me que vem e você aqui conhecerá outros índios. Não tenha medo porque esses têm evoluído, segundo os autores, e não sei se são mais ou menos ladrões (Carta de Manuel Mañkelef para Rodolfo Lenz: 22/10/1912).
\end{abstract}

A escrita de Manuel Mañkelef pode ser entendida a partir de um viés irônico ou não. No entanto, em ambas as interpretações, traduz-se a presença do imaginário social do estigma de ladrão, atribuído aos povos indígenas, e que, ainda hoje, lamentavelmente, permanece presente em alguns discursos proferidos no cotidiano do Chile, assim como de outros países latino-americanos. Ao contrário desse discurso de Mañkelef, em que permanece a dúvida se ele estaria recorrendo à ironia, Tomás Guevara 
escancarou na sua escrita o pressuposto de que o povo mapuche era uma "raça bárbara", "inferior" e "com deficiência intelectual". A partir desse olhar para o povo mapuche, Guevara apontou uma solução educacional para o concebido "problema indígena" (Guevara 1911: 193).

O desejo de alcançar a chilenidad, concebida como civilização, repercute na ânsia de Tomás Guevara em eliminar o cacique da redução, enxergando-o como a supremacia da interdição. Considerado como um entrave à civilização, Tomás Guevara classificou-o como "inútil e mantenedor das regras tradicionais" (Guevara 1902; III: 495).

O entendimento do cacique como uma barreira à civilização também ressoou no discurso de Manuel Mañkelef, que, em uma das reuniões da Sociedad Caupolicán, assinalou a necessidade de "excluir a liderança dos caciques, porque muitos, para não dizer todos, são ignorantes que não conhecem as vantagens do homem civilizado [...]" (La época 14/12/1910 apud Donoso 2012: 112).

Dessa forma, ser civilizado correspondia a enquadrar-se dentro dos parâmetros da chilenidad, enquanto a existência da cultura mapuche era entendida como um "problema" a ser solucionado. A educação passou a ser enxergada como um viés para diluir essa cultura, criando a percepção de ser o caminho para solucionar o dito "problema". Bernardo Subercaseaux afirma que, dentro desse contexto do final do século XIX e começo do XX, em que as teorias raciais ocuparam destaque no meio intelectual, a educação passou a ser percebida "como o eixo que permitiria integrar e construir a nação" (Subercaseaux 2011; I: 353).

Tomás Guevara, além de ter escrito diversos livros sobre a cultura mapuche, debruçou-se também sobre uma "solução" educacional para o concebido problema desse povo, a qual transparece em sua participação nos congressos de educação $(1902,1912)$, nos quais expôs a temática da educação indígena; no desenvolvimento de livros, como Enseñanza indígena; assim como na participação na Sociedad Caupolicán.

Tanto Manuel Neculman como Manuel Mañkelef e Tomás Guevara ocuparam cargos importantes na Sociedad Caupolicán. Enquanto Guevara foi o presidente honorário (1910-1914), Neculman, em 1910, e Mañkelef, em 1916, assumiram o posto de presidente dessa organização mapuche. Fundada em 1910, foi a primeira organização política contemporânea mapuche, que visava à incorporação gradual desse povo aos valores ocidentais por meio do acesso à educação tradicional (Serrano et al. 2003; I: 310; Foerster e Montecino 1988: 16; Pinto 2003: 205). Dessa forma, ressoa na fundação dessa organização a dicotomia entre civilização e barbárie, propalada por Domingo Sarmiento, fundador da Escuela Normal de Preceptores.

No entanto, cabe enfatizar que a Sociedad Caupolicán surgiu também com o intuito de defender os interesses do povo mapuche, que vinha sofrendo violências físicas e usurpações de suas terras. Tomás Guevara evidencia esse objetivo no discurso proferido na comemoração do primeiro ano da Sociedad Caupolicán (1911). Ele diz:

Antes se defendiam com as armas, agora devem se defender com a instrução: para não ficarem totalmente vencidos, mandem seus filhos para escolas, liceus, etc. Assim a geração futura substituirá dignamente os seus antecessores (DA 12/07/1911 apud Foerster e Montecino 1988: 17).

Apesar de Guevara ter enaltecido o papel da educação indígena como forma de obter um "proveito real da obra larga e complexa da assimilação", ele ponderou que "em todas as épocas da história deste povo, o ensino indígena foi um fracasso" (Guevara 1908: 393). Enfim, Guevara alegou que o ensino religioso não tinha conseguido cumprir o papel do "melhoramento moral e intelectual do índio" (Guevara 1908: 394).

Partindo de um pensamento racial, Guevara argumentou que a "raça araucana" era inferior, apresentando "caráter infantil com relação às raças superiores", apontando a "necessidade" de desenvolver "um plano de ensino araucano", exigindo "a fundação de escolas exclusivamente indígenas e graduadas de acordo com programas especiais" (Guevara 1908: 399).

Nos congressos de educação de 1902 e 1912, que aconteceram em Santiago de Chile, Guevara apresentou trabalhos sobre a educação indígena e a "solução educacional". Nas atas desses congressos está a proposta de uma metodologia específica para a educação indígena, tendo como meta a condução "gradual e paulatina à prática de alguns ramos da ciência agrícola" (Congreso Jeneral de Enseñanza Pública 1904; I: 185-186). Para Guevara, o ponto fundamental do programa dessa metodologia era “[...] fazer do índio um cultivador útil dos seus 
campos, onde possa colher os benefícios dos seus esforços e o amor tão arraigado em seus costumes do solo de seus antepassados"( Congreso Jeneral de Enseñanza Pública 1904; I: 187).

Cabe questionarmos aqui a visão de Tomás Guevara perante Manuel Mañkelef, que, apesar de ter sido um dos principais colaboradores de suas pesquisas, tinha sobre si, por ser mapuche, o olhar etnocentrista e racial de Guevara. Convém também ponderarmos o olhar de Mañkelef sobre o povo mapuche, assinalando diferenças e semelhanças entre o seu discurso e o de Guevara. No entanto, antes de desdobrarmos esses questionamentos, abordaremos as trajetórias de vida e o modo como foi se constituindo a relação entre esses dois intelectuais.

\section{Trajetória de Tomás Guevara e (des)enlaces com Manuel Mañkelef}

Tomás Guevara, membro de uma elite cultural, foi reconhecido por seus pares, no meio intelectual e entre os políticos. Na Biblioteca Nacional do Chile há epistolografias de Tomás Guevara com Ricardo Latcham e Pedro Montt. No Fondo Rodolfo Lenz, da Universidad Metropolitana de Ciencias de la Educación (UMCE), encontram-se outras cartas trocadas com Lenz.

No Diccionario Histórico Biográfico de Chile consta que Tomás Guevara ocupou diversas comissões em nome do Conselho de Instrução e do Ministério de Instrução Pública. Entre essas, podemos citar: delegado ao Congresso de Americanistas em Washington; delegado ao Congresso de Americanistas de Buenos Aires (1910); delegado ao Congresso de História e Americanista de Educação Secundária, que ocorreu no Rio de Janeiro (1922) (Figueroa 1929: 394).

Guevara foi também membro das seguintes instituições estrangeiras: Sociedade de Geografia do Rio de Janeiro, Sociedade Internacional de História de Paris, Sociedade de Americanistas de Paris, Junta de Historia e Numismática de Buenos Aires (Figueroa 1929: 395). Além disso, participou da Sociedade Americanista de Berlim, bem como foi acadêmico honorário da Facultad de Filosofia y Letras da Universidad de la Plata e da Sociedade Chilena de Historia y Geografía (El Colono 30/04/1987; n. 3928: s/pág.).

A trajetória de Tomás Guevara desvela um estudioso do povo mapuche e uma pessoa dedicada à educação em todo o transcorrer da vida. Teve sua formação no Instituto Nacional e em liceus provinciais, estudando humanidades e matemática. Muito jovem, participou da Guerra do Pacífico, incorporando o ideário positivista também por esse viés. Foi ao Peru com o batalhão de Valdivia e tornou-se capitão nas batalhas de Tacna, Chorrillos e Miraflores. Depois de regressar da guerra, em 1884, com dezenove anos de idade, Guevara foi contratado como professor no Liceo de Curicó. Nessa cidade, exerceu também os cargos de prefeito, de chefe do corpo de bombeiro e de administrador do estabelecimento de beneficência (Figueroa 1929: 394).

Em 1892, Guevara mudou-se para Angol, onde trabalhou como professor de castelhano e secretário do intendente de Malleco (Figueroa 1929: 394). Vinculado ao Liceo de Angol, fundou o Museu Arqueológico, que foi destruído pela enchente de 1904 (El colono 30/04/1987; n. 3928: s/pág). Nesse período, Guevara começou a desenvolver pesquisas etnográficas sobre o povo mapuche, e, com a colaboração de Lorenzo Coliman, escreveu Historia de la Civilización de la Araucanía (1898). No mesmo ano de publicação do seu livro, Tomás Guevara foi contemplado com um prêmio pela Facultad de Humanidades da Universidad de Chile.

Um ano após o reconhecimento de seu livro pela Universidad de Chile, Guevara foi nomeado o segundo reitor do Liceo de Hombres de los Hombres de Temuco, permanecendo no cargo de 1899 a 1913. Como reitor, Guevara esforçou-se para melhorar o espaço físico e as condições de aprendizagem desse estabelecimento. Cabe pontuar que, no início de sua gestão, o liceu funcionava em uma casa precária na rua Antonio Varas, e, depois de suas reivindicações, conseguiu mudá-lo para uma propriedade maior, localizada na rua Claro Sollar (Rubio 2011: 12).

Foi nesse estabelecimento de educação tradicional chilena que, em 1900, Manuel Mañkelef e Tomás Guevara se conheceram. Guevara acabara de assumir o cargo de reitor do liceu, onde era também professor de castelhano, e Mañkelef iniciava os estudos ali, após ter concluído a sua formação na escola primária que Manuel Antonio Neculman dirigia.

Mañkelef, depois de ter estudado no Liceo de los Hombres de Temuco, lecionou na Escuela Normal de Chillán e em outros colégios. Em 1909, regressou para o Liceo de los Hombres de Temuco como professor de educação física, caligrafia e colaborador das pesquisas que Tomás Guevara desenvolvia sobre o povo mapuche (Guevara e Mañkelef 2002 [1913]: 19-20). 
Guevara pôde aprofundar seus estudos etnográficos sobre o povo mapuche no período em que viveu em Angol e em Temuco, região que tinha sido recém-incorporada ao Chile, com terras antes dominadas pelo povo mapuche, que as reivindica até os dias atuais. Cabe lembrar que a tomada de Villarrica ocorreu em 1883 e que Tomás Guevara mudou-se para Angol nove anos depois, em 1892. Em 1899, foi nomeado reitor do liceu de Temuco, permanecendo no cargo até 1913, ano de publicação da Las últimas familias i costumbres araucanas.

Guevara nasceu em Curicó e, assim como o seu irmão Rubén, se dedicou à educação. Rubén Guevara, em 1876, iniciou suas atividades no Liceo de Curicó como professor de matemática, onde permaneceu por trinta anos como reitor (Figueroa 1929: 394). Segundo familiares de Guevara, parece que não existia muita afinidade entre eles, talvez porque competissem entre si.

Assim como Tomás Guevara tinha dificuldade em relacionar-se com o seu irmão, deixou vestígios também de desentendimentos com Manuel Mañkelef e com muitos professores do Liceo de los Hombres de Temuco. Mañkelef, em uma das cartas a Rodolfo Lenz, descreveu a fase final de Guevara nesse liceu:

Em poucos dias mais, parece que teremos neste liceu um grande escândalo, pois parece que, pelo que vi hoje, foi pedida a renúncia de um professor e este a solicitou por assuntos particulares, baseando-se em que o sábio reitor de Temuco realizou um roubo de uns quantos mil. Darei mais detalhes, porque vários professores, senão todos, terão que esclarecer o assunto (Carta de 13/03/1913, escrita por Mañkelef para Lenz, Arquivo Rodolfo Lenz).

Depois de mencionar esse episódio, Mañkelef ironicamente diz, em carta de 14 de abril de 1913, que:

Por outra parte, o psicólogo T.G passa agora por uma questão complicada e está mal com a maioria dos professores. Implica com todos e nos irrita (Carta de 14/04/1913, escrita por Mañkelef para Lenz, Arquivo Rodolfo Lenz).

Mañkelef, ao referir-se a Tomás Guevara como psicólogo, estava ironicamente expondo a sua aversão ao livro Psicolojía del pueblo araucano, criticando-o claramente na carta escrita em 18 de setembro de 1913. Ao pedir para Rodolfo Lenz uma sugestão de livro de fonética, Mañkelef mencionou: "Li a conferência de frei Jerônimo e é notável, farei uma crítica e atacarei seriamente o autor de Psicolojía araucana".

Nesse mesmo ano de 1913, Guevara deixou o cargo de reitor do Liceo de los Hombres de Temuco e foi nomeado, pelo Conselho de Instrução, como o primeiro reitor do Liceo Victorino Lastarría, em Santiago de Chile, onde aposentou-se em 1927 (Figueroa 1929: 394).

Em 28 de abril de 1914, Manuel Mañkelef, mais uma vez, escreveu para Rodolfo Lenz evidenciando a repulsa que adquiriu por Tomás Guevara. Mañkelef propalou a emergência de expulsá-lo da Sociedad Caupolicán, dizendo: “[...] Que me diz de T.G.; amanhã começarei pois a aborrecer as pessoas falando sobre o papel que desempenha com a raça araucana e a necessidade de expulsá-lo da Sociedad Caupolicán".

A epistolografia de Manuel Mañkelef para Rodolfo Lenz demonstra a ruptura de Mañkelef com Guevara, de quem se distanciou no mesmo período em que se aproximou de Lenz. Ao considerarmos esse (des)enlace das vidas de Tomás Guevara e Manuel Mañkelef, cabe lembrar que, assim como ambos participaram ativamente da Sociedad Caupolicán, fundada em 1910, também atuaram como sócios na Sociedad de Folklore Chileno, fundada em 1909 por Rodolfo Lenz (Dannemann 2000-2001: 336). Dois anos após a fundação dessa sociedade, Tomás Guevara publicou Folklore araucano (1911) e Manuel Mañkelef Comentarios del pueblo araucano (1911), o qual foi dedicado à Manuel J. Ortiz e ao dr. Rodolfo Lenz. Esse livro, além de ter sido prefaciado por Rodolfo Lenz, ganhou prêmio nacional, sendo publicado nos Anales da Universidad de Chile e na Revista Folklore Chileno. Enfim, Mañkelef passou a ser reconhecido no círculo intelectual em que Lenz se movia: o de Santiago e o da Universidad de Chile.

No prefácio de Comentarios del pueblo araucano (1911), Lenz enalteceu a importância dos estudos de Mañkelef dizendo:

O trabalho que se publica, nas páginas que seguem, reveste-se de um interesse particular por ser uma absoluta novidade nos Anales da Universidad de Chile. É a primeira vez 
que um descendente imediato da heroica raça cantada por Ercilla, um jovem que em sua infância não falou outra língua que o mapuche, publica uma obra científica. É verdade que já mais de uma vez, relações, descrições de costumes e outras notícias interessantes devido à pluma de Manquilef têm visto a luz por meio da imprensa, incorporadas nas importantes obras que o sábio e assíduo etnólogo don Tomás Guevara publicou com o título "Psicolojía del pueblo araucano"(1908), e "Folklore araucano" (1911). Mas, nessas ocasiões, o índio não tinha sido mais que o colaborador de seu mestre. Hoje se apresenta sozinho na arena (Mañkelef 1911; II: 4).

Assim como Tomás Guevara competia com o seu irmão Rubén, que também trabalhava na área de educação, cabe refletir que a inserção de Mañkelef, "sozinho na arena" na Sociedad de Folklore Chileno e no meio acadêmico da Universidad de Chile, provavelmente deve ter incomodado a autoestima desenvolvida de Guevara. Não podemos esquecer que, no imaginário social de Tomás Guevara, Mañkelef não era apenas outro intelectual que estudava um tema correlato, como no caso do seu irmão, e sim um mapuche, o qual era concebido por ele como uma "raça inferior" fadada ao desaparecimento.

Las últimas familias $i$ costumbres araucanas foi publicado em 1913, no mesmo ano em que Tomás Guevara vivenciou os desentendimentos no Liceo de los Hombres de Temuco, mudando-se dessa cidade para Santiago de Chile. Ao analisar as cartas escritas de Mañkelef para Lenz e deparar-nos com o prefácio de Las últimas familias i costumbres araucanas, publicado no mesmo período, é interessante notar que, apesar de Mañkelef descrever para Lenz uma relação conturbada com Tomás Guevara, isso não transparece na escrita de Guevara, no prefácio de seu livro, em que o define como um "normalista e inteligente professor do liceu de Temuco" (Guevara 1913: 4). Talvez Guevara o tenha enaltecido, apesar de a relação pessoal entre os dois estar alterada, com o intuito de valorizar o próprio livro que, segundo ele, teria "uma novidade muito marcada por ser em sua primeira parte uma história araucana escrita por araucanos. Talvez seja a única de sua espécie em nosso país e ainda em nos outros do continente sul-americano" (Guevara 1913: 3). No entanto, dois anos antes, no prefácio de Comentarios del pueblo araucano (1911), Rodolfo Lenz já tinha enaltecido o trabalho de Manuel Mañkelef por ser "a primeira vez que um descendente imediato da raça cantada por Ercilla" publicava um trabalho científico, escrevendo-a nos dois idiomas que dominava "com igual perfeição". Coincidência ou não, Guevara adotou a mesma estrutura da escrita de duas colunas, em castelhano e mapundugun, utilizada por Manuel Mañkelef em Comentarios del pueblo araucano. Isso nos leva a considerar a hipótese de que o fato de Mañkelef ter estreado sozinho na "arena" acadêmica da Universidad de Chile, provavelmente deve ter incomodado Guevara, que estabelecia anteriormente uma relação de domínio na apropriação do saber, tanto de Mañkelef como de Coliman, na escrita dos seus livros. Talvez o próprio Rodolfo Lenz, por estudar o mapundugun e a cultura mapuche, almejasse ocupar o papel que Tomás Guevara tinha estabelecido com Manuel Mañkelef, nos anos em que Guevara foi reitor do Liceu de Temuco. Enfim, a relação de poder, no âmbito de escritor e diretor, diante do colaborador de estudos etnográficos e professor do mesmo liceu.

André Menárd, ao abordar a obra de Manuel Mañkelef, em "Emergencia de la tercera columna en un texto de Manuel Manquilef", pondera a presença de uma "genealogia colonial" na estrutura de colunas mapundugun-castelhano, que Rodolfo Lenz distinguiu como o idioma dos civilizados e o dos não civilizados. Menárd analisou que:

\footnotetext{
De fato, para o científico alemão, as culturas e suas línguas se ordenam segundo graus diversos, medíveis por sua capacidade de abstração. Dessa forma ratifica cientificamente a assimetria das colunas e as ordena em função de um acima e um abaixo, de uma maturidade e um infantilismo, em que o termo superior sempre poderá compreender em sua capacidade de abstração o termo inferior (Menárd 2006; II: 932).
}

Florencia E. Mallon, em "La 'doble columna' e la 'doble consciencia' en la obra de Manuel Manquilef", também analisa o prefácio escrito por Rodolfo Lenz em Comentarios del pueblo araucano, percebendo-o com uma postura de "“autoridade científica' que avalia o valor e a legitimidade do trabalho de Manquilef" (Mallon 2010; XXI: 62). Dessa forma, "Manquilef passa de ser autoridade 
cultural e científica cujo trabalho ganhou um concurso nacional, a ser objeto de análise do 'esperto' e 'científico' Lenz” (Mallon 2010; XXI: 63).

A importância de nos debruçarmos sobre as obras de Tomás Guevara e de Manuel Mañkelef, analisando os (des)enlaces de suas vidas e de suas escritas, consolida-se ao descolonizarmos esse imaginário social, construído no final do século XIX e início do XX, mediante a interferência dos pressupostos das teorias positivo-evolucionistas, que ainda hoje apresentam vestígios.

\section{Folclore, etnografia, História}

Em meados do século XIX, os estudos etnográficos e folclóricos surgiram enquanto uma imposição de uma concebida verdade e não como uma representação de culturas e acontecimentos. Esses estudos entrelaçaram-se com a constituição da chilenidad, a qual mobilizava um olhar colonizador com o intuito de reforçar os valores dessa "comunidade imaginada".

Tomás Guevara, Manuel Mañkelef e Rodolfo Lenz participaram, segundo Fernando Fischman, da primeira suposta associação de folclore da América Latina: Sociedad de Folklore Chileno (Fischman in Bendix et al. 2012: 265). Rodolfo Lenz, além de ser o fundador dessa associação, foi também um dos precursores no campo de estudos folclóricos, publicando sua obra Estudios araucanos em 1895-1897. Fernando Fischman, em "Folklore and Folklore studies in Latin America", analisa que Rodolfo Lenz delimitou a importância de se estudar a língua mapundugun, passando pelas narrativas pessoais, descrição de cerimônias e cantos, enquanto pesquisa de produção cultural (Fischman in Bendix et al. 2012: 267). Essa direção no campo de estudos folclóricos, como assinala Fischman, posteriormente ficou a cargo do campo da etnografia e da etnolinguística (Fischman in Bendix et al. 2012: 267). Não é de se estranhar que a Sociedad de Folklore Chileno, em 1911, dois anos depois de sua fundação, tenha se incorporado à Sociedad Chilena de Historia y Geografia.

A etnografia e o folclore foram estudos entendidos como um modo de capturar os povos indígenas, que apesar de fazerem parte da história nacional, eram compreendidos como fósseis vivos de uma época passada, que deveria ser analisada a partir da ciência. Seguindo esse raciocínio, Tomás Guevara afirmou:

\begin{abstract}
A historiografia chilena progrediu muito nos últimos dez anos. Na atualidade, não é raro, pois, encontrar alguns vazios nos trabalhos de tempo anterior. Contudo, permanece sobre nossos aborígenes na "Araucania" um abundante material de fato, reunido em um corpo só e de fácil consulta para professores e etnógrafos (Guevara 1905:35).
\end{abstract}

No Congreso Nacional de Enseñanza Secundária (1912), Guevara apresentou trabalhos na sessão de educação indígena, bem como na de História e Geografia. Nessa última sessão, Guevara reivindicou a importância dos estudos etnográficos no Chile, recordando: "Os estudiosos de etnografia têm estado no Chile até a atualidade em um esquecimento mais ou menos completo, seja com recursos universitários, seja em sua relação com o ensino de história" (Guevara in Congreso Nacional de Enseñanza Secundaria 1912; IV: 57).

Ao abordar a importância da etnografia para o ensino de História, Guevara instituiu a "fossilização" dos povos indígenas, ao afirmar:

Semelhante deficiência envolve um erro grave no ensino de História. O estudante não forma um conceito geral do desenvolvimento nacional sem o estudo do homem pré-histórico, nem das frações bárbaras sobreviventes com rastros ainda de costumes tão primitivos e rudimentares como os daquele. Ignora como as sociedades mais adiantadas passaram por períodos de evolução análogos aos nossos (Guevara in Congreso Nacional de Enseñanza Secundaria 1912; IV: 57).

Ao constatar e realçar a importância da etnografia, diante de parâmetros etnocêntricos e de um arsenal teórico positivo-evolucionista, Guevara propôs a incorporação da etnografia no programa escolar:

Nosso programa é suscetível de conter a maior soma de noções de etnografia, no mínimo.

Metodicamente distribuído nos seis anos de humanidades, este conteúdo poderia incorporar as seguintes matérias, para os distintos grupos aborígenes que existem e que ainda subsistem em nosso território: O meio físico. 
Características físicas dos habitantes.

Características linguísticas.

Características sociológicas (vida material e psíquica ou jogos e passatempos, artes e religião; vida familiar e social).

Este é o plano adotado pelos argentinos para os estudos elementares de etnografia, com as variantes de particularidades que especializam cada coletividade indígena. No quinto e sexto ano se completaria o conjunto com a inclusão de dados sobre a etnografia da América do Sul e a psicologia dos aborígenes chilenos.

Os povos compreendidos na etnografia chilena seriam os peruanos, os atacamas, os changos, os araucanos, chonos e freguinos (Guevara in Congreso Nacional de Enseñanza Secundaria 1912; IV: 58).

Como forma de incentivar e despertar o interesse dos alunos para o campo de pesquisa etnográfica, Guevara propôs também a "organização de museus provinciais em alguns liceus do país", afirmando que a valorização dos estudos etnográficos acarretaria rapidamente "progressos que a história geral obteria com tão eficaz auxiliar" (Guevara in Congreso Nacional de Enseñanza Secundaria 1912; IV:58).

Destarte, para Tomás Guevara, a importância do estudo da etnografia fundamentava-se a partir de um olhar evolucionista, que configurava os povos indígenas como pertencentes a tempos pretéritos. Seria importante estudá-los, em função de estarem prestes a desaparecer. Esse pensamento reverberou na escolha do título de Las últimas familias $i$ costumbres araucanas.

\section{Reflexões Finais Concepção de "predisposição característica do bárbaro": espaço essencial da exclusão}

A partir desse imaginário social, em que Tomás Guevara classificou o mapuche entre as "frações bárbaras sobreviventes" desse tempo pretérito, devemos recordar que Guevara propôs também uma metodologia especial para o povo mapuche que ponderasse as concebidas características da "raça araucana", entendidas como deficiência de aprendizagem e "caráter infantil em relação às raças superiores". No entanto, será que essa "solução educacional", apresentada por Guevara para o presumido "problema indígena", aceitaria integralmente a inserção do mapuche "civilizado" na sociedade chilena?

Apesar de Guevara ter participado da Sociedad Caupolicán, associação contemporânea mapuche que visava proteger os mapuche da usurpação das terras e da violência que esse povo vinha sofrendo, a proposta dessa associação, assim como a metodologia educacional proposta por Guevara, pautava-se pela inserção e pela transformação do mapuche dentro dos moldes da chilenidad. Enfim, a concebida "solução educacional", moldada diante de um olhar racial e evolucionista, visava exterminar o sujeito mapuche, portador de uma cultura distinta da chilenidad, protegendo o indivíduo que deixasse de ser mapuche e se tornasse chileno. Porém, diante do fio condutor racial, a incorporação do mapuche "civilizado" e educado tradicionalmente, dentro do padrão chileno, se depararia com o obstáculo racial que permitiria apenas a aproximação do sujeito "civilizado". Segundo Guevara, a existência de uma "herança bárbara", faria com que o mapuche "civilizado" alcançasse apenas uma aproximação das concebidas "raças superiores".

Guevara pontua: "A influência da educação nos indígenas é inegável, mas seus efeitos se manifestam de um modo muito lento, porque persistem por muito tempo as tendências hereditárias" (Guevara 1913: 4).

Assim, Tomás Guevara delimitou:

Os araucanos poderiam, sem dúvida, alcançar formas de atividades mentais próximas da nossa, mas nunca chegariam a uma igualdade completa. Fala-se da média e não das exceções; é evidente que mais próximo ficará o sujeito saído do seu meio e reconstruído pela educação na lógica da raça superior (Guevara [1916] 2012: 608).

Seguindo esse raciocínio, para Guevara, apesar de Manuel Mañkelef ter se distanciado da cultura mapuche, ao incorporar a cultura entendida como civilizada por meio da educação tradicional chilena, ele jamais conseguiria alcançar a "igualdade completa" da classificada "raça superior" devido "às tendências hereditárias". Como afirma José Ancan Jara, Mañkelef, por ser filho de um mapuche com uma cativa "branca", recaía sobre ele um olhar "racial" que o enquadrava como mestiço, que, enxergado "a partir do lado chileno, não o redimiu e sim reforçou a sua metade "bárbara"” (Ancan 2014: 7). 
Portanto, Mañkelef, por ser mapuche, no discurso de Tomás Guevara, não conseguiria desprender-se da concepção de "predisposições das características do bárbaro" (Guevara 1902, III: 530). Poderia assimilar-se à chilenidad, mas nunca conseguiria desvincular-se dessa. Ou seja, a presença da concepção dessas "tendências hereditárias" imobilizava Mañkelef e os povos indígenas na sua identidade de Outro excluído (Guevara 1913: 4).

Como esclarece Zygmunt Bauman, devemos lembrar que o próprio processo de assimilação é "sempre um processo unidirecional -indiretamente reafirma o que era para ser provado-a superioridade e a benevolência dos governantes" (Bauman 1999: 80).

Destarte, Tomás Guevara, ao propor a assimilação do mapuche, concebido como "inferior", "débil" e com as "características de um povo bárbaro", simultaneamente estava afirmando a superioridade da chilenidad e propunha o que hoje poderíamos clas-sificar como etnocídio.

Ou seja, apesar de Guevara e Mañkelef defenderem o povo mapuche da violência física, que vinha sofrendo com o processo conhecido como "ocupação da Araucanía", que poderíamos classificar como desocupação do território do povo mapuche, Guevara, assim como Mañkelef, por meio da justificativa de assimilação cultural mapuche, propunha um etnocídio com uma máscara de defesa. Enfim, como Zygmunt Bauman menciona, "o que se exige dos 'culturalmente estranhos' por meio do autorrefinamento é, em última análise, a eliminação da sua origem" (Bauman 1999: 82). Ou seja, nesse caso, a eliminação do povo e da cultura mapuche.

\section{Referências Citadas}

Ancan Jara, J.

2014 De Küme molfüñche a "civilizados a medias": liderazgos étnicos e intelectuales mapuche en la Araucanía fronteriza (1883-1930). Polis [em línea], 38,2014. Publicado em 3 de setembro de 2014. Disponível em: <http:// polis.revues.org/ 10013>. Acesso em 17 de dezembro de 2014.

Bauman, Z.

1999 Modernidade e ambivalencia. Trad. Marcus Penchel. Jorge Zahar, Rio de Janeiro.

Bengoa, J.

2000 Historia del pueblo mapuche: (siglo XIX-XX). Lom Eds., Santiago.

Boccara, G. e I. Seguel-Boccara

1999 Políticas indígenas en Chile (siglo XIX y XX) de la asimilación al pluralismo -El caso Mapuche-Revista de Indias, Vol. LIX, $\mathrm{N}^{\circ}$ 217: 741-774.

Congreso Jeneral de Enseñanza Pública de 1902 Actas I Trabajos 1904 Vol. I. Trabajos. Santiago de Chile: Imprenta, Litografía y encuadernación Barcelona.

Congreso Nacional de Enseñanza Secundária

1912 Resúmenes de algunos temas del Congreso. Imprenta Universitária: Santiago de Chile. Boletim No 3, Septiembre.

Dannemann, Manuel

2000-2001 "Vida y obra de Rodolfo Lenz". Revista chilena de antropología, $\mathrm{N}^{\circ}$ 8, 1989-1990. Facultad de Ciencias Sociales, Universida de Chile, pp. 331-339.

Donoso Romo, A

2012 Educación y nación al sur de la frontera. Organizaciones mapuche en el umbral de nuestra contemporaneidad, 18801930. 2.ed. Pehuén, Santiago de Chile.

Figueroa, V.

1929 Diccionario Histórico Biográfico de Chile. Bacells $\&$ Co, Santiago de Chile.

Fischman, F

2012 Folklore and Folklore studies in Latin America. In: A companion to Folklore, editado por Bendix, Regina F. et al. (org), pp. 265-285. Blackwell publishing, UK.
Foerster, R. e Montecino, S.

1988 Organizaciones, lideres y contiendas Mapuches (19001970). CEM, Santiago de Chile.

Graham, R. (Edited)

2006 The idea of race in Latin America, 1970-1930. Institute of Latin American Studies, University of Texas, Austin. [Kindle].

Guevara, T. e Mankelef, M.

2002 [1913] Kiñe mufü trokiñche ñi piel. Historias de familias siglo XIX. Prefácio: José Ancan, CEDM Liwen, Temuko.

Guevara, T.

1904 Enseñanza indíjena. In: Congreso Jeneral de Enseñanza Pública de 1902. Actas I Trabajos, Vol. I, pp. 173-188. Imprenta, Litografía y Congreso encuadernación Barcelona, Santiago de Chile.

Guevara, T.

1905 El libro "raza chilena" $i$ sus referencias sobre el sur. Impr. Alemana, Temuco.

Guevara, T.

1911 Folklore Araucano. Imprenta Cervantes, Santiago de Chile.

Guevara, T.

1902 Historia de la civilización de Araucanía. Los araucanos y la Republica. Tomo III. Imprenta Barcelona, Santiago.

Guevara, T.

2013 La mentalidad araucana Anales de la Universidad de Chile, Norteamérica, 01911 2012. Disponível em: <http:// www.revistas.uchile.cl/index.php/ANUC/article/viewArticle/24427/25780>. Acesso em 18 de março.

Guevara, T.

1913 Las últimas familias y costumbres araucanas. Imprenta Cervantes, Santiago.

Guevara, T.

1908 Psicolojía del Pueblo araucano. Imprenta Cervantes, Santiago.

Guevara, T.

1912 Sección de Historia y geografía. In: Congreso Nacional de Enseñanza Secundaria. Resúmenes de algunos temas del congreso. Boletin $\mathrm{N}^{\circ} 4$ Septiembre, Imprenta Universitaria, Santiago. 
Mallon, F.E.

2010 La "doble columna" y la "doble conciencia" en la obra de Manuel Manquilef. Revista de Antropología, 21: 59-80, Universidad de Chile, Santiago.

Mañkelef, M.

1911 Comentarios del Pueblo Araucano. Revista de la Sociedad de Folklore Chileno, n. 1 Tomo II. Consultado 04 de janeiro 2015. URL: http://www.memoriachilena.cl/archivos2/pdfs/ MC0008915.pdf

Menárd, A

2006 Emergencia de la tercera columna en un texto de Manuel Manquilef. Anales de Desclasificación, 1: 927-937.

Núñez Prieto, I.

2010 Las escuelas normales: una historia de fortalezas y debilidades. 1842-1973. Revista Docencia, 40: 32-39, Colegio de Profesores, Santiago de Chile. Pasta de Cautín. Archivo de la Araucanía.

Pinto Rodríguez, J.

2003 La formación del Estado y la Nación, y el pueblo mapuche: de la inclusión a la exclusión. Centro de Investigaciones Diego Barros Arana, Santiago.

Prado, M.L. e Pellegrino, G.

2014 História da América Latina. Contexto, São Paulo.
Reunião de 30 de mayo de 1898, Annales de la Universidad de Chile.

Rubio Seguel, M.

2011 Reseña histórica del primer liceo de la Frontera (18882011). Imprenta Austral, Temuco.

Sol Serrano, et al.

2013 Historia de la Educación en Chile (1810-2010). Tomo I. Taurus, Santiago de Chile.

Subercaseaux, B.

2011 Historia de las ideas y de la cultura en Chile. Desde la Independencia hasta el Bicentenario. Vol. I. Editorial Universitaria, Santiago de Chile.

\section{Archivos y Fuentes Primarias}

Archivo de la Araucanía, Carpeta de Cautín.

Carta de Manuel Mañkelef para Rodolfo Lenz 13/03/1913. Archivo Rodolfo Lenz.

Carta de Manuel Mañkelef para Rodolfo Lenz 14/04/1913. Archivo Rodolfo Lenz.

Carta de Manuel Mañkelef para Rodolfo Lenz 22/10/ 1912. Archivo Rodolfo Lenz.

El colono 1987. Angol, 30 de abril, año XIV, No 3928. 
ANDROS IMPRESORES

www.androsimpresores.cl 

